\title{
Arachnoid Cyst with a Non-traumatic Acute Subdural Hematoma in an Eleven-year-old Patient
}

\section{Cisto aracnoide associado a hematoma subdural agudo não traumático em um paciente de onze anos de idade}

\author{
Gabriel Flamarin Cavasana ${ }^{1}$ Rodrigo Mendonça ${ }^{1}$ Fabricio Willian Mantelo Zanini ${ }^{1}$ \\ ${ }^{1}$ Neurosurgery Department of Santa Casa de Misericórdia de \\ Araçatuba, SP, Brazil \\ Address for correspondence Gabriel Flamarin Cavasana, Medical \\ Student, Rua Ipanema, 67, Apto 52-C, São Paulo, SP 03164200, Brazil \\ (e-mail: gcavasana@hotmail.com).
}

Arq Bras Neurocir 2017;36:122-124.

\begin{abstract}
Keywords

- neurosurgery

- arachnoid cysts

- acute subdural hematoma

\section{Resumo}

Palavras-chave

- neurocirurgia

- cisto aracnoide

- hematoma subdural agudo

A non-traumatic intra-cystic hemorrhage in an arachnoid cyst is a rare event, with few cases reported in the literature. We present a case of an eleven-year-old boy patient, which presented a spontaneous acute subdural hematoma and intra-cystic hemorrhage after a strong headache episode. The results were evidenced by a computed tomography $(C T)$ scan and surgical findings. We perform a brief literature review on the arachnoid cyst and its suggested treatments. In our case, the patient underwent a surgical treatment with a complete resolution of the case.

Sabe-se que uma hemorragia intracística não traumática em um cisto aracnoide é um acontecimento raro, com poucos casos relatados na literatura. Nós apresentamos o caso de um menino de onze anos de idade, o qual apresentou espontaneamente um hematoma subdural agudo acompanhado de hemorragia intracística após um forte episódio de dor de cabeça. Os resultados foram evidenciados através de uma tomografia computadorizada e dos achados cirúrgicos. Foi feita uma breve revisão da literatura sobre cisto aracnoide e seus respectivos tratamentos sugeridos. Em nosso caso, o paciente foi submetido a um tratamento cirúrgico, com resolução completa do caso.
\end{abstract}

\section{Introduction}

The arachnoid cyst is presumably a congenital malformation and represents only $1 \%$ of all intracranial lesions. ${ }^{1}$ Its rupture and bleeding are rare, usually occurring in young adults and associated with trauma. Risk of hemorrhage does not exceed $0.04 \% /$ year. $^{2}$ We report a case of an eleven-year-old boy with a previously asymptomatic arachnoid cyst that suddenly presented a non-traumatic acute subdural hematoma and intra-cystic hemorrhage.

received

June 29, 2015

accepted

November 23, 2015

published online

February 12, 2016

$10.1055 / \mathrm{s}-0035-1571137$ ISSN $0103-5355$.

\section{Case}

An eleven-year-old boy had a sudden episode of headache of moderate intensity accompanied by nausea. The child denied any history of chronic headache before this episode. The symptoms began appearing at a monthly frequency. Every time, the boýs parents would medicate symptoms with oral analgesic, after which he evolved with improvement. After five months, the headache episodes became weekly and more

Copyright $\odot 2017$ by Thieme Revinter

Publicações Ltda, Rio de Janeiro, Brazil

License terms 
intense associated with nausea and vomiting, varying in location. Oral analgesics were no longer effective to solve the pain. There were no other associated symptoms. The parents decided to take the patient to the emergency service, where he had a cranial CT scan. This one showed an arachnoid cyst in the middle fossa of the left cerebral hemisphere, without signs of complications ( - Fig. 1). The local neurologist evaluated him and initiated a conservative treatment of the headache. After about a month with worsening symptoms, the patient returned to the emergency service, where he had a new cranial CT scan that showed an acute subdural hematoma (-Fig. 2). He was referred to the neurosurgeon local service, where there was a decision made to hospitalize the patient and provide surgical treatment.

The surgical technique was decompressive craniotomy with a question-mark incision and a whole hematoma evacuation. There was intracystic hemorrhage observed during the surgery. The patient remained in the pediatric intensive care unit due to postoperative support, showing gradual improvement. The patient received a medical discharge after seven days. After 30 days, he had a new CT. This last CT scan showed no bleeding. Based on the CT findings and the absence of pathological signs and symptoms, we concluded there had been a complete resolution of the condition (-Figs. 3-4).

\section{Discussion}

Intracranial arachnoid cysts are relatively common findings in neuroimaging studies among the pediatric population, primarily in boys. ${ }^{3}$ The most accepted hypothesis states that the arachnoid cyst is a congenital malformation. ${ }^{1}$

The arachnoid cyst corresponds to $1 \%$ of all non-traumatic intracranial lesions. The most common location is the middle cranial fossa. ${ }^{4}$ It is presumably formed by a division of the arachnoid membrane caused by an increase in cerebrospinal fluid (CSF) pressure. ${ }^{1}$ Other hypotheses are: 1-dysgenesis

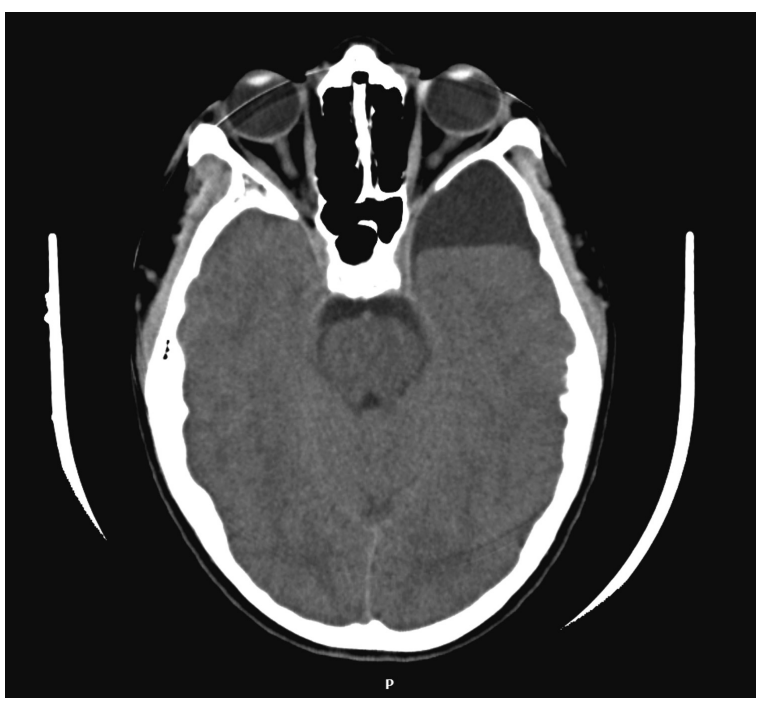

Fig. 1 Arachnoid cyst without bleeding. Exam date: May 28, 2014.

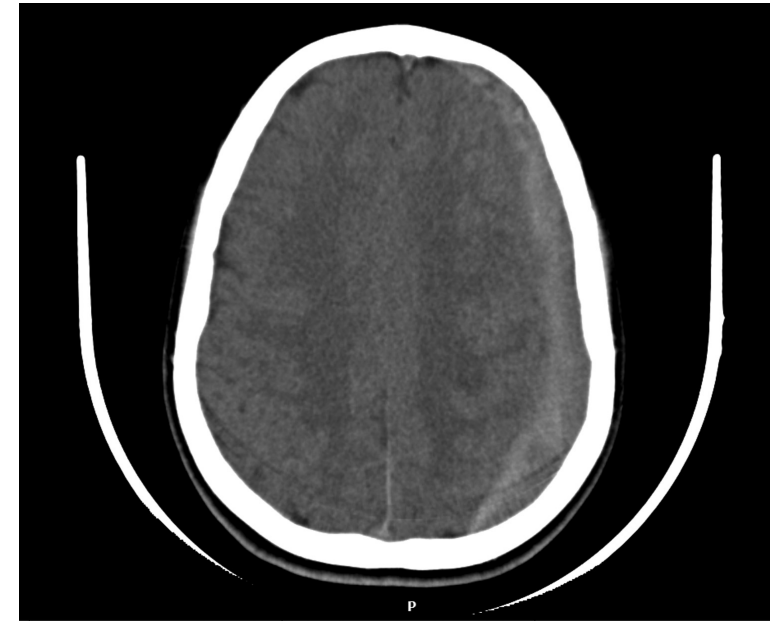

Fig. 2 Acute subdural hemorrhage. Exam date: July 4, 2014.

embryo in the formation of the arachnoid, secondary to a primary disorder of the mesenchyme adjacent to the neural tube; 2-agenesis, located atrophy or hypoplasia of the brain resulting in the secondary expansion of the CSF space; 3located disorder secondary to infectious/inflammatory process, traumatic or hemorrhagic. ${ }^{5}$ Most imaging studies findings are incidental due to the asymptomatic clinic nature of the arachnoid cysts. The risk of bleeding does not exceed $0.04 \%$ per annum. ${ }^{2}$ When bleeding does occur, most cases are associated with head injury. In this case, there was no report of injury, which makes this case even rarer. The most plausible hypothesis was spontaneous bleeding. According to Patel et al, the source of the bleeding was in the communicating vessels between the dura and the outer face of the cystic membrane. ${ }^{6}$ Bleeding may occur not only in the cyst, but in the subdural and epidural extra space as well. ${ }^{1}$ However,

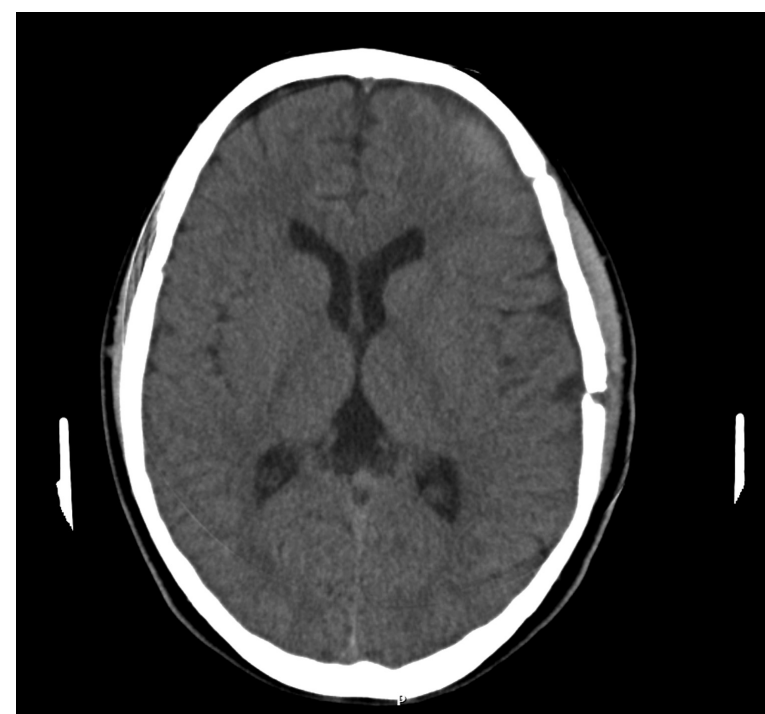

Fig. 3 The CT scan after a month of the craniotomy showing the resolution of the subdural hemorrhage. Exam date: August 6, 2014. 


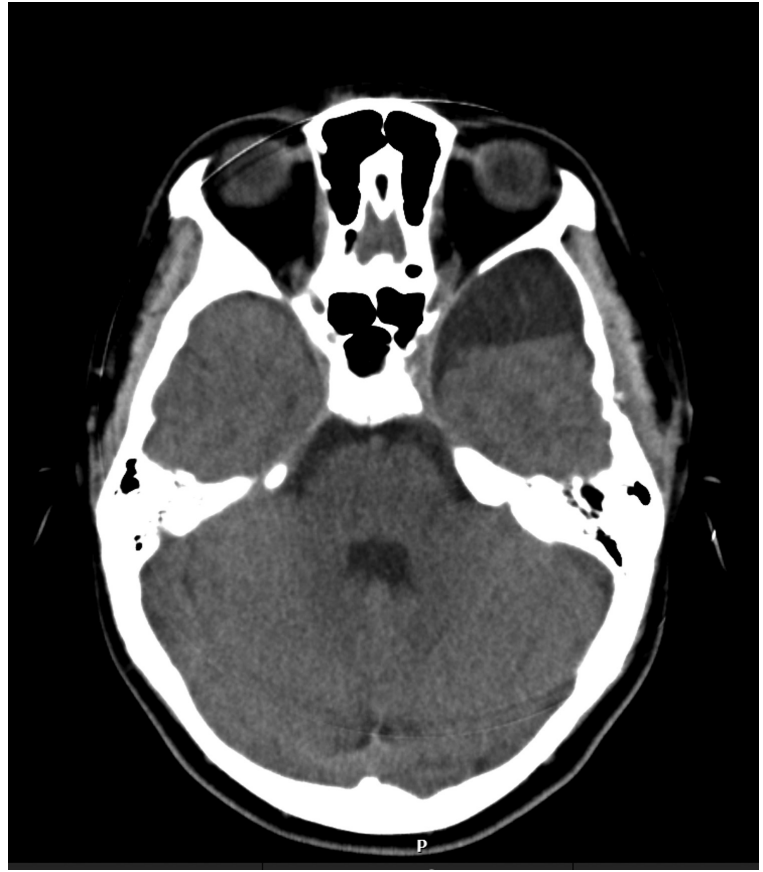

Fig. 4 Arachnoid cyst without bleeding. Exam date: August 6, 2014.

intra-cystic hemorrhage is an extremely rare complication, which still remains with its pathogenesis unknown. ${ }^{1}$ This complication was visibly present in our patient.

In a case-control study, we observed that the larger the cyst size, especially if the cysts have a maximum diameter larger than $5 \mathrm{~cm}$, the greater the chance of disruption and associated complications, such as hygroma, subdural hematoma, and intra-cystic bleeding. ${ }^{7}$

Moreover, signs of intracranial hypertension, seizures, macrocrania, and delayed development in the last thirty days must be considered warning signs of cyst rupture. ${ }^{2}$

Based on the literature reviewed, treatment is essentially surgical, although largely contingent on the patients symptoms. Surgery is indicated when there are important symptoms and/or complications of the disease. In asymptomatic patients, there is no consensus in the literature for the surgical treatment.

We found that patients with symptomatic arachnoid cysts can safely undergo a key-hole craniotomy and drainage procedure with reported success. ${ }^{6,8}$

\section{Conclusion}

Arachnoid cysts are usually incidental findings in neuroimaging and more common in pediatric patients, appearing asymptomatic in most cases. Its pathophysiology is currently not well explained. The diagnosis is well established by a head CT without contrast or MRI. The literature also suggests that vascular imaging tests should be requested for patients with arachnoid cyst who presented headache. ${ }^{9}$

The most common symptom in this case is the headache. Treatment is primarily surgical in symptomatic cases and/or when complications are present. Patients with arachnoid cyst with presence of warning signs should be investigated for rupture and bleeding of the lesion.

\section{Complementary Information}

We conducted this study at the institution Santa Casa de Misericórdia de Araçatuba, in the town of Araçatuba, in the state of São Paulo, Brazil.

\section{References}

1 Akyuz M, Goksu E, Aralasmak A, Tuncer R. Retroclival arachnoid cyst presenting with haemorrhage: a brief report of a special case. Acta Neurochir (Wien) 2010;152(1):161-162

2 Henriques JGB, Pianetti Filho G, Henriques KSW, et al. Spontaneous acute subdural hematoma contralateral to an arachnoid cyst. Arq Neuropsiquiatr 2007;65(4A, 4a)1034-1036

3 Hong JC, Kim MS, Chang CH, Kim SH. Arachnoid cyst with spontaneous intracystic hemorrhage and chronic subdural hematoma. J Korean Neurosurg Soc 2008;43(1):54-56

4 Iaconetta G, Esposito M, Maiuri F, Cappabianca P. Arachnoid cyst with intracystic haemorrhage and subdural haematoma: case report and literature review. Neurol Sci 2006;26(6):451-455

5 Zanini MA, Gabarra RC, Faleiros AT, Freitas CC, Alves A. [Cerebral aneurysm and arachnoid cyst: about a case with intracystic hemorrhage]. Arq Neuropsiquiatr 2000;58(2A):330-335

6 Patel RA, Levy ML, Crawford JR. Spontaneous subdural haemorrhage in a child with bilateral middle cranial fossa arachnoid cysts. BMJ Case Rep 2013;2013:xx

7 Cress M, Kestle JR, Holubkov R, Riva-Cambrin J. Risk factors for pediatric arachnoid cyst rupture/hemorrhage: a case-control study. Neurosurgery 2013;72(5):716-722, discussion 722

8 Scheel M, Bauknecht HC. Teaching neuroimages: head banging without head trauma: subdural hemorrhage in association with arachnoid cysts. Neurology 2011;76(12):e60

9 Shimizu J, Matsumoto M, Yamazaki E, Yasue M. An aneurysm rupturing into a middle cranial fossa arachnoid cyst presenting as an intracystic hemorrhage. J Stroke Cerebrovasc Dis 2012;21(3): 243-244 